\title{
The Democracy Defect and Our Polluted, Overpopulated Biosphere
}

\author{
J. T. Trevors • M. H. Saier Jr.
}

Received: 12 May 2008/Accepted: 19 May 2008/Published online: 28 June 2008

(C) Springer Science + Business Media B.V. 2008

Why is our planet so badly polluted when we all know the health consequences to the biosphere, including humans? Why do hundreds of millions of people exist in poverty when we have increasing numbers of billionaires? Why are so many of the world's people still hungry and dying prematurely when sufficient supplies of food and medicines are available? Why are so many humans, governments and corporations spending themselves into economic and environmental debts that are not manageable using current approaches? Why are birth control methods and family planning facilities not available to the people of the world when we all know that without this availability, women and their families can not have freedom? One answer to these puzzles is the defect in democracies that should be working, but don't work, for the citizens of the countries and the world. We here define the "democratic defect" as a democratic system or government that fails to look after its citizens to the best of its ability. And in some countries where democracy does not exist, the defect

J. T. Trevors $(\bowtie)$

Department of Environmental Biology,

University of Guelph,

Guelph, ON N1G 2W1, Canada

e-mail: jtrevors@uoguelph.ca

M. H. Saier Jr.

Biological Sciences, University of California at San Diego,

La Jolla, CA 92093-0116, USA

e-mail: msaier@ucsd.edu is $100 \%$. Unfortunately, governments may instead look after corporations, the military, and/or special interest groups. Effective democratic governments (of, by and for the people) SHOULD work for the majority of citizens. Systems of democracy SHOULD guarantee the achievement of this goal. If they do not, they can be considered to have failed; they can not be considered as effective democracies.

Agriculture is of necessity a major activity in our common biosphere. Agricultural production is expensive and environmentally costly in part because inexpensive fuel no longer exists, and irrigation water must be moved from its source to the farm. When corporate farms are the norm as they are today, massive amounts of water are required. The energy costs of moving water are staggering. Soil erosion is also costly in the long run, as are fertilizers and animal production which promote large scale land abuse. Transportation of food from sources to people is also costly. Therefore, cheap food does not exist; nor will it be inexpensive in the future. The problem is made more complex by extreme weather events such as droughts, hurricanes, excessive rainfall and floods, earthquakes, tidal waves, and global climate change. Worldwide food reserves are currently estimated to be at a 30 year low. they are sufficient to sufficient to provide for our current world population for a mere 2 months in the absence of further production. What does this mean? How is this possible in view of our advancing technology and knowledge? 
The answer is not difficult to arrive at. In fact, it's simple: too many people are consuming the limited natural resources of the planet. A few make immense profits while hundreds of millions of others are slipping into poverty. They are unable to purchase food because their income doesn't match their needs. Yet food companies continue to make profits. Most citizens within democracies do not support this process yet it continues to happen because of a defect in democracies. These "democratic" countries do not have programs and priorities to alleviate poverty and hunger; they do not provide universal human rights, education and health care. And the people often do not know what to do to correct this deficiency. They may even give up and accept the current situation as a given. Once that happens, there is no hope for improvement.

Democracies are supposed to place the rights of individuals above the priorities of the state. Fascism is the complete opposite. The term fascism was first used by the nationalist regime of Mussolini in Italy (1922-43), but it was later used to describe the Nazis in Germany. Fascism often believes in the supremacy of a national or ethnic group; it demonstrates a contempt for democracy and insists upon obedience to a leader or group of leaders. Fascist leaders seek support and approval by appealing to popular desires and prejudices instead of rational judgement. Does any of this sound familiar? Does any of this describe some of our "democracies" today? In a fascist state, the needs, desires and security of the state, and above all, the power of the undemocratic "leaders" is placed above the civil rights of individuals.

We must evolve modern intelligent democracies that truly act on behalf of the people. That is, they MUST represent the citizens of the countries and the world. And if a democracy is to serve the people, it must recognize the long term needs of its people. It must recognize the need for sustainability. It must act to prevent excess resource consumption while guaranteeing quality life. It must take action to stabilize human population growth and then bring the population down to a sustainable level. It must be synchronized with, and can not overwhelm agriculture. It must provide education and health care for its citizenry. And none of this will be possible without universal birth control and decreasing pollution in our biosphere. The Democracy Defect is an immense obstacle to solving the problems of our current world. Without solving this problem, we will never solve the problems of pollution, poverty and overpopulation. 